\title{
ROVE BEETLES OF THE GENUS GYROPHAENA (COLEOPTERA, STAPHYLINIDAE, ALEOCHARINAE) OF UKRAINE
}

\author{
S. V. Glotov ${ }^{1}$, A. A. Petrenko' , A. Yu. Mateleshko ${ }^{3}$ \\ ${ }^{1}$ Lugansk Nature Reserve, NAS of Ukraine, \\ Rubezhnaya str., 95, Stanichno-Luganskoye, Lugansk Region, 93600 Ukraine \\ E-mail: glotov2006@rambler.ru \\ ${ }^{2}$ Schmalhausen Institute of Zoology, NAS of Ukraine, \\ Bogdan Chmielnitski str., 15, Kyiv, 01601 Ukraine \\ ${ }^{3}$ Uzhgorod National University, A. Voloshyn str., 32, Uzhgorod, 88000 Ukraine \\ E-mail: mateleshko@rambler.ru
}

Received 14 April 2010

Accepted 15 March 2011

\begin{abstract}
Rove Beetles of the Genus Gyrophaena (Coleoptera, Staphylinidae, Aleocharinae) of Ukraine. Glotov S. V., Petrenko A. A., Mateleshko A. Yu. - Twenty species of the genus Gyrophaena Mannerheim, 1830, from Ukraine are reviewed. Of these, five species: G. joyi Wendeler, 1924; G. joyioides Wüsthoff, 1937; G. orientalis A. Strand, 1938; G. pseudonana A. Strand, 1939 and G. williamsi A. Strand, 1935, are recorded from Ukraine for the first time. Detailed morphological descriptions, data on bionomics and distribution are given for each species. A key to all subgenera and species of the genus Gyrophaena occurring in Ukraine is provided.
\end{abstract}

Key words: rove beetles, Coleoptera, Staphylinidae, Gyrophaena, Ukraine.

\begin{abstract}
Жуки-стафилиниды рода Gyrophaena (Coleoptera, Staphylinidae, Aleocharinae) фауны Украины. Глотов С. В., Петренко А. А., Мателешко А. Ю. - Дан обзор 20 видов рода Gyrophaena Mannerheim, 1830 фауны Украины. Среди выявленных видов 5 ( G. joyi Wendeler, 1924; G. joyioides Wüsthoff, 1937; G. orientalis A. Strand, 1938; G. pseudonana A. Strand, 1939 и G. williamsi A. Strand, 1935) впервые приведены для фауны Украины. Даны детальные морфологические описания, указаны особенности экологии и распространения для всех 20 видов. Приведена таблица для определения подродов и видов рода Gyrophaena фауны Украины.
\end{abstract}

Ключе вы е слова: жуки-стафилиниды, Coleoptera, Staphylinidae, Gyrophaena, Украина.

\section{Introduction}

The rove beetle genus Gyrophaena Mannerheim, 1830, includes 562 described species in the world fauna (Newton et al., 2005). Of these, 193 species are known from the Palearctic Region (Löbl, Smetana, 2004), including 20 species in the fauna of Ukraine. Larvae and adult beetles of Gyrophaena are obligate fungivores feeding on mature spores, basidium, or fungal hyphae, scraping spores off from the surface of fungal hemenium (Ashe, 1984; Seevers, 1951). Several species can form mass aggregations in one fungal body, and particular species are repeatedly found together in one complex of co-existing species. Some species of Gyrophaena demonstrate associations with particular species of fungi (Nikitskij et al., 1996). All species of this genus are widespread in all natural zones of Ukraine, and some of them are dominants among the fauna of particular species of fungi.

Taxonomic and faunistic knowledge of Gyrophaena is extremely fragmentary both at the global and Palearctic scale. The fauna of Northern and Central Europe is better studied, with comprehensive papers including keys available for these territories (Erichson, 1837; Freude et al., 1974; Ganglbauer, 1895; Joy, 1912; Klimaszewski et al., 2009; Likovsky, 1964; Scheerpeltz, Höfler, 1948; Strand, 1935, 1938, 1939, 1946, 1968; Wüsthoff, 1937). The Eastern and Southern Europe is less studied in this respect. There were no special publications on the fauna 
of this genus in Ukraine. The present paper is an attempt to fill the gap in the local knowledge of Gyrophaena, an ecologically notable genus of rove beetles.

\section{Material and methods}

The material examined is deposited in the following collections and was examined through the kindness of the following curators: I. I. Schmalhausen Institute of Zoology, National Academy of Sciences of Ukraine, Kyiv (SIZK), A. A. Petrenko; National Natural History Museum of the National Academy of Sciences of Ukraine, Kyiv (NHMK), V. V. Barabanova; Zoological Museum of Taras Shevchenko National University, Kyiv (ZMTSNU), M. M. Bilyashivskiy; State Museum of Nature, Lviv (SMNL), V. B. Rizun, T. P. Yanitskij; Museum of Natural History, Vienna (NHMW), H. Schillhammer; Zoological Museum, Natural History Museum of Denmark, Copenhagen (ZMUC), A. Solodovnikov; collection of L. I. Fally, Dnipropetrovsk (CF); collection of S. V. Glotov, Lugansk (CG); collection of A. V. Gontarenko, Odessa (CGo); collection of S. V. Konovalov, Tryohizbenka village, Lugansk Region (CK); collection of A. Yu. Mateleshko, Uzhgorod (CM).

All species descriptions were made based on our own examination of specimens and using various previous taxonomic literature (Erichson, 1837; Freude et al., 1974; Ganglbauer, 1895; Hochhuth, 1872; Joy, 1912; Likovsky, 1964; Scheerpeltz, Höfler, 1948; Strand, 1935, 1938, 1939, 1946, 1968; Williams, 1927; Wüsthoff, 1937). Current taxonomic status of the species, spellings of the authors' names, dates of publication of subgenera and species names follow Löbl and Smetana (2004). Mass material from Russia, and Europe (material from ZMUC, NHMW, and from the private collections of J. Pedersen (Copenhagen) and M. Schülke (Berlin), was used for comparison with specimens from Ukraine.

Abbreviations of the collecting localities with their coordinates are as follows: Andriyivka - Novomoskovskiy District, Andriyivka Village: 48 45'53.49" N 35²7'33.54" E; Biletskivka - Svitlovodskii District, Biletskivka Village: 491'59.89" N 332'31.46" E; Borodyanskiy - Borodyanskiy District: 50³8'31.19" N 2949'17.21" E; Buzhora -

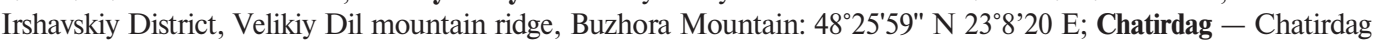

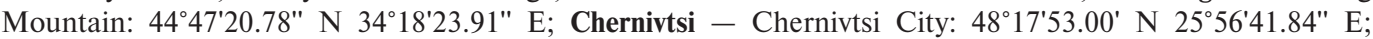

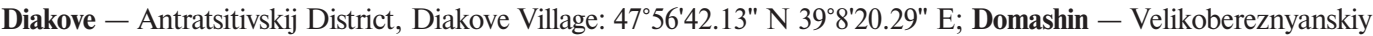
District, Domashin Village: 48 $58^{\prime} 11.91^{\prime \prime}$ N 22³3'5.68" E; Domashinskiy Verh - Velikobereznyanskiy District, Domashin Village, Domashinskiy Verh Mountain: 4858'31.94" N 22³7'7.92" E; Donetsk - Donetsk City: 4759'13.71" N 3745'51.92" E; Dubki - Uzhgorodskiy District, Dubki Hole: 4867'07.71" N 22³6'43.15" E; Golosieve - Golosiyivskij District, Golosievsky Park: 50²3'25.78" N 30³0'33.79" E; Gorodishe - Bilovodskiy District, Gorodishe Village: 49³'19.95" N 39³8'46.88" E; Gostra Mogila - Lugansk City, Gostra Mogila Park: 48³1'12.75" N 39²0'20.86" E; Hydropark - Kyiv, Hydropark: 50²6'35.52" N 30³4'48.14" E; Kamjanitsya Uzhgorodskiy District, Kamjanitsya Village: 4869'65.69" N 2241'58.28" E; Kaniv - Kanivskiy District, Kaniv

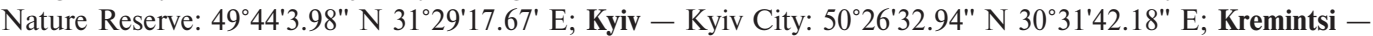
Nadvornyanskiy District, [Kremintsi Village]: 48³3'30.85" N 2428'57.53" E; Kuziy — Rahivskiy District, Kuziy

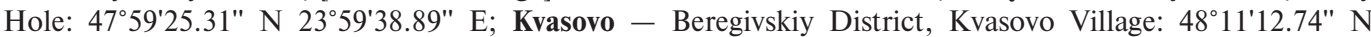
$22^{\circ} 46^{\prime} 18.31^{\prime \prime}$ E; Lukovitse - Kanivskiy District, Lukovitse Village: 4957'41.67" N 3124'19.16" E; Lviv - Lviv City: 4950'31.59" N 242'44.17" E; Malaya Ugolka - Tyachev District, Malaya Ugolka Village: 48¹0'37.80" N

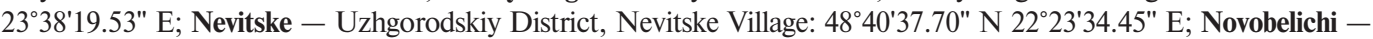
Novobelichi: District, 50²7'21.77" N 30²0'1.18" E; Onokivtsi - Uzhgorodskiy District, Onokivtsi Village: $48^{\circ} 39^{\prime} 12.14^{\prime \prime}$ N 22²0'26.47" E; Orihovitsya - Uzhgorodskiy District, Orihovitsya Village: 48³9'8.88" N $22^{\circ} 23^{\prime} 48.40^{\prime \prime}$ E; Otok - Beregivskiy District, hole Otok: 48¹2'21.15" N 2243'0.98" E; Plishka - Perechinskiy District, Plishka Mountain: 4873'99.46" N 22³9'85.48" E; Provalskiy Step - Sverdlovskiy District, Nature Reserve Provalskiy Step: 487'20.59" N 3948'56.86" E; Rahiv - Rahivskiy District, Rahiv City: 48³'16.73" N $24^{\circ} 12^{\prime} 46.54^{\prime \prime E}$; Roztochchya - Yavorivskiy District, Nature Reserve Roztochchya: $49^{\circ} 55^{\prime} 7.11^{\prime \prime}$ N 234' $54.88^{\prime \prime}$ E; Shirokiy Lug - Tyachivskiy District, Shirokiy Lug Village: $48^{\circ} 12^{\prime} 46.34^{\prime \prime}$ N 234ㄴ $17.38^{\prime \prime}$ E; Siruy potik Uzhgorodskiy District, Syruy potik Hole: 4871'86.33" N 22³9'66.10" E; Stanichno-Luganskiy - Stanichno-

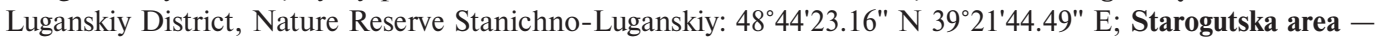
Seredino-Budskiy District, Desnyansko-Starogutskiy National Park, Starogutska Area: 52²0'12.10" N $33^{\circ} 25^{\prime} 38.70^{\prime \prime}$ E; Stavne - Velikobereznyanskij District, Stavne Village: 4859'30.03" N 2241'34.49" E; Strichava - Velikobereznyanskiy District, Strichava Village: 48 57'34.24" N 22²9'7.53" E; Svalyava -

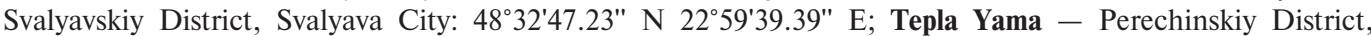
Tepla Yama Hole: 48 44'32.08" N 22²5'9.97" E; Terebovlya - Terebovlyanskiy District, Terebovlya Village $49^{\circ} 17^{\prime} 51.41^{\prime \prime}$ N 2542'9.16" E; Teremki - Golosiyivskiy District, Teremki: 50²1'52.26" 30²7'14.27" E; Tovstij Grun - Rahivskiy District, Tovstiy Grun Hole: 487'27.46" N 2415'45.30" E; Troitske - Bilyayivskiy District,

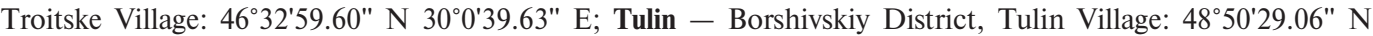

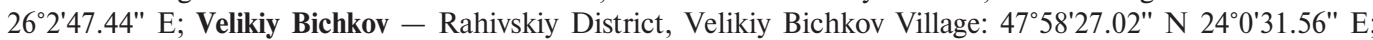
Vorochevo - Perechinskiy District, Vorochevo Village: 4842'36.95" N 22²6'59.58" E; Zarichevo - Perechinskiy

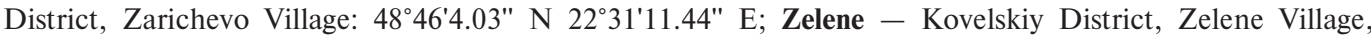

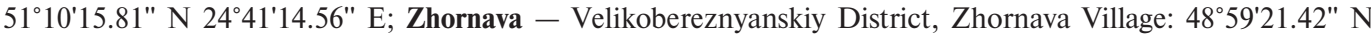
$22^{\circ} 38^{\prime} 15.51^{\prime \prime} \mathrm{E}$. 


\section{Review of species}

\section{Gyrophaena affinis Mannerheim, 1830}

Hochhuth, 1872: 112; Cherkunov, 1889: 159; Jakobson, 1905-1915: 533; Smetana, 2004: 446; Mateleshko, 2005: 129.

Material examined. Volyn Region: Zelene 32 ex., 12.08.1988 (SIZK); Donetsk Region: Donetsk, 6 ex., 27.08.1999 (SIZK); Transcarpathian Region: Domashin, 4 ex., 27.07.2001; Buzhora, 2 ex., 1.08.2002; Plishka, 3 ex., 28.10.2004; Vorochevo, 2 ex., 29.04.2001; Zarichevo, 11 ex., 20.08.2001; Nevitske, 1 ex., 24-31.05.2001; 1 ex., 814.08.2001; 5 ex., 19.05.2002; 9 ex., 28.07.2002; Onokivtsi, 1 ex., 13.08.2001; Orihovitsya, 4 ex., 26.05.2002 (CM); Kyiv: «K.» [Kyiv], 3 ex., undated, (NHMK); Teremki, 5 ex., 19.07.1980; Novobelichi, 10 ex., 19.08.1984; 8 ex., 14.07.1985 (SIZK); Kirovograd Region: Biletskivka, 35 ex., 12.08.1982 (SIZK); Lugansk Region: Gostra Mogila, 302 ex., 28.05.2007; 2 ex., 28.05.2007; 3 ex., 13.06.2008; Provalskiy Step, 3 ex., 12.07.2008; 11 ex., 13.07.2008; Stanichno-Luganskiy, 10 ex., 17.06.2007; 14 ex., 24.06.2007; 11 ex., 22.07.2007; 2 ex., 8.07.2008; 1 ex., 20.07.2008 (CG); Lviv Region: Lviv, 1 ex., undated; 1 ex., 25.05.[?]; 1 ex., 10.06.[?] (SMNL); Roztochchya, 2 ex., 10.06.1990 (SIZK); Ternopil Region: Tulin, 1 ex., 7.05.[?] (SMNL); Cherkasy Region: Kaniv, 3 ex., 10.09.1987 (SIZK); 3 ex., 20.07.2008 (CG); Lukovitse, 4 ex., 04.06.1999 (SIZK); Chernivtsi Region: «Bukowina, Cernowitz» [Chernivtsi], 2 ex., undated (ZMTSNU).

Description. Body length 1.7-2.3 mm. Head black, sometimes dark brown. Pronotum dark brown. Elytra yellow-brown with somewhat infuscated posterior angles. Abdomen brown, its 5th and 6th tergites black. Antennae and legs yellow. Vertex with 10 small, round, distinct punctures on each lateral side. Antennae: 5th segment square or slightly elongate, $6-10$ th segments almost of quadrate shape, each slightly widened apicad. Pronotum smooth medially, with sparse, rounded punctures laterally; pronotum 1.4-1.5 times as wide as long. Elytra with even, dense, coarse, large punctation. Entire body with faint, reticulate microsculpture. Male: posterior margin of 7 th abdominal tergite medially with one large, deep, rounded puncture. 8th abdominal tergite: with small, dense punctuation at anterior margin; smooth and glossy, without any punctuation or microsculpture medially; with 2 long, weakly sharpened and inwards curved processes laterally at prosterior margin (fig. 1, 1). Aedeagus (fig. 2, 1).

Bionomics. The species inhabits xylotrophic and terraneous gill-bearing and tubular fungi (Rusch, 1990; Nikitskij et al., 1996). Adults are active from May to September.

Distribution. Widely distributed in the Holarctic: Northern Africa (Algeria, Morocco, Tunisia); Eurasia (entire Europe, Turkey, Caucasus, Siberia, Russian Far East and North Korea); North America (Seevers, 1951; Horion, 1967; Smetana, 2004).

\section{Gyrophaena bihamata Thomson, 1867}

Roubal, 1930: 418; Bogdanov, 1985.

Material examined. Transcarpathian Region: Domashin, 1 ex., 27.07.2001 (CM); Kyiv: Hydropark, 2 ex., 14.06.2006 (SIZK); Golosieve, 5 ex., 09.09.2008; Novobelichi, 23 ex., 12.08.1984 (SIZK); Cherkasy Region: Kaniv, 2 ex., 20.07.2008 (CG); Lukovitse, 1 ex., 04.06.1999 (SIZK); Kirovograd Region: Biletskivka, 8 ex., 12.08.1982 (SIZK); Lviv Region: Lviv, 1 ex., undated; 1 ex., 12.04.1917 (SMNL).

Description. Body length 1.7-2.2 mm. Head black. Pronotum red-brown, sometimes brown, with narrow pale brown margin at base and laterally. Elytra yellow-brown with slightly darkened posterior angles. Abdomen red-brown, with 6th tergite black. 1-4th antennal segments pale yellow, 5-11th red-brown. Legs yellow-brown. Vertex with 3-5 small punctures on each lateral side. Middle of pronotum with 2 longitudinal rows of 3 or 4 large, round, distinct punctures each. Head and pronotum with dense and distinct reticulate microsculpture. Elytra with dense, coarse, small punctation. Male: posterior margin of 7 th abdominal tergite medially with one row of longitudinal, long and short striae; posterior margin of 8th abdominal tergite laterally with 1 long processes, weakly pointed and slightly curved inwards (fig. 1, 2). Aedeagus (fig. 2, 2). 

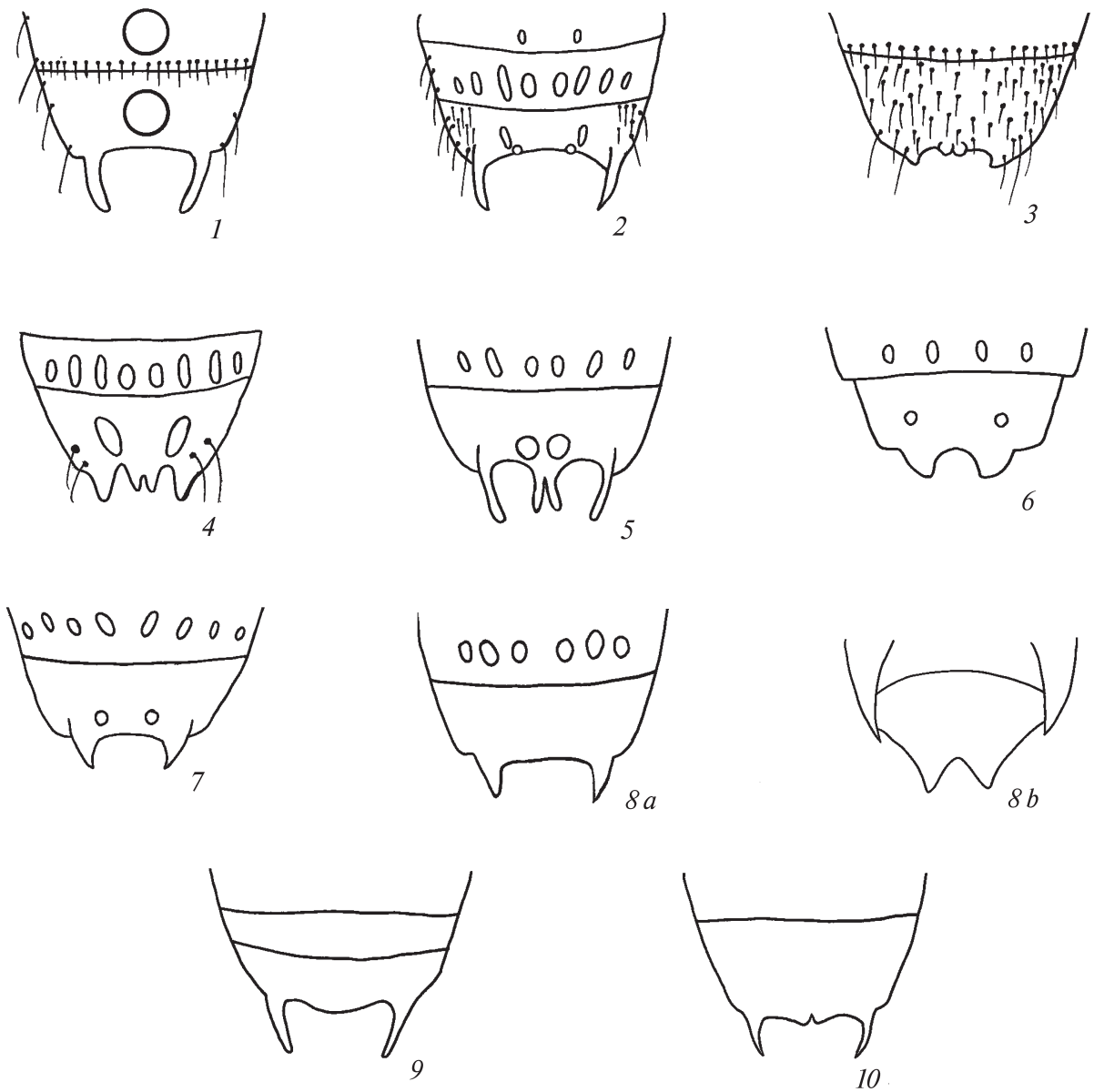

Fig. 1. 7th, 8th and 9th abdominal tergites of male: $1-$ G. affinis; $2-$ G. bihamata; $3-$ G. boleti; $4-G$. congrua; 5-G. gentilis; 6-G. fasciata; $7-G$. joyi; $8 a-G$. joyioides (7-8 abdominal tergites); $8 b-G$. joyioides (9th abdominal tergites); $9-G$. lucidula; $10-G$. manca; 1-3, 5-10- redrawn from Wüsthoff, 1937; 4 - original.

Рис. 1. Седьмой, восьмой и девятый тергиты самца: $1-$ G. affinis; $2-$ G. bihamata; 3 - G. boleti; $4-$ G. congrua; $5-$ G. gentilis; $6-$ G. fasciata; $7-$ G. joyi; $8 a-$ G. joyioides (7-8-й тергиты); 8 b - G. joyioides (9-й тергит); $9-$ G. lucidula; $10-$ - . manca; 1-3, 5-10 - по: Wüsthoff, 1937; 4 - оригинальный.

Bionomics. The species inhabits xylotrophic and terraneous gill-bearing and tubular fungi. Usually it is not found in high quantity of specimens, but sometimes they forming large swarms. Adults are active from May to September (Rusch, 1990; Nikitskij et al., 1996).

Distribution. Palearctic species: North Africa (Algeria, Tunisia), Europe, Russia (European territory, Siberia and Far East), North Korea, Turkey (Horion, 1967; Smetana, 2004).

Gyrophaena congrua Erichson, 1837

Hochhuth, 1871: 112; Jakobson, 1905-1915: 533.

Material examined. Kyiv: «K.» [Kyiv], 4 ex., undated, (Hochhuth) (NHMK); Crimea: Chatirdag, 1?, 26.08.1978 (Petrenko) (SIZK).

Description. Body length $1.5-2 \mathrm{~mm}$. Head black, matt. Pronotum dark brown, glossy with narrow pale brown margin at base and laterally. Elytra yellow-brown with slightly darkened posterior angles. Abdomen yellow-brown, 5-7th tergites black. 1-4th anten- 
nal segments pale yellow, 5-11th red-brown. Legs yellow-brown. Vertex with sparse, small, round punctation on each half. Middle of pronotum with 2 longitudinal rows of 6 or 7 large, round, distinct punctures each. Elytra with even, dense, coarse, large punctures. Entire body with dense and distinct reticulate microsculpture. Male: posterior margin of 7th abdominal tergite medially with one row of longitudinal, long and short striae, medially of 8th abdominal tergite with 2 rounded striae. Middle of posterior margin of 8th tergite with two very short pointed appendages, and laterally, on each side, with moderately long, rather blunt and hardly inward curved process (fig. 1, 4). Aedeagus (fig. 2, 4).

Bionomics. The species inhabits xylotrophic and terraneous gill-bearing and tubular fungi. They do not form large swarms. Adults are active from May to September (Rusch, 1990; Nikitskij et al., 1996).

Distribution. Holarctic species: Europe, Russia (European territory and East Siberia), Caucasus; North America (Horion, 1967; Smetana, 2004).

Gyrophaena gentilis Erichson, 1839

Roubal, 1930: 418; Bogdanov, 1985.

Material examined. Volyn Region: Zelene 18 ex., 11.08 .1988 (SIZK); Transcarpathian Region: Vorochevo, 5 ex., 3.06.2001; 4 ex., 15.07.2007; Tepla Yama, 3 ex., 23.08.2003 (CM); Svalyava, 6.05.1996 (SIZK); Malaya Ugolka, 12 ex., 25-29.07.2007; Shirokiy Lug, 8 ex., 18-20.09.2006 (CGO); Nevitske, 86 ex., 15.06.2001; 7 ex., 19.05.2002; 3 ex., 28.07.2002; Onokivtsi, 2 exs., 19-24.07.2001; Orihovitsya, 1 ex., 22.05.2004 (CM); Kyiv: Golosieve, 42 ex., 09.09.2008 (SIZK); Kyiv Region: Borodyanskiy, 52 ex., 20.05.1996 (SIZK); Lviv Region: Roztochchya, 1 ex., 24.08.1988; 397 ex., 10.06.1990 (SIZK).

De s criptio n. Body length 2.2-2.4 mm. Head black. Pronotum brown, sometimes dark brown. Elytra yellow-brown. Abdomen pale brown, 6th tergite dark brown, some-
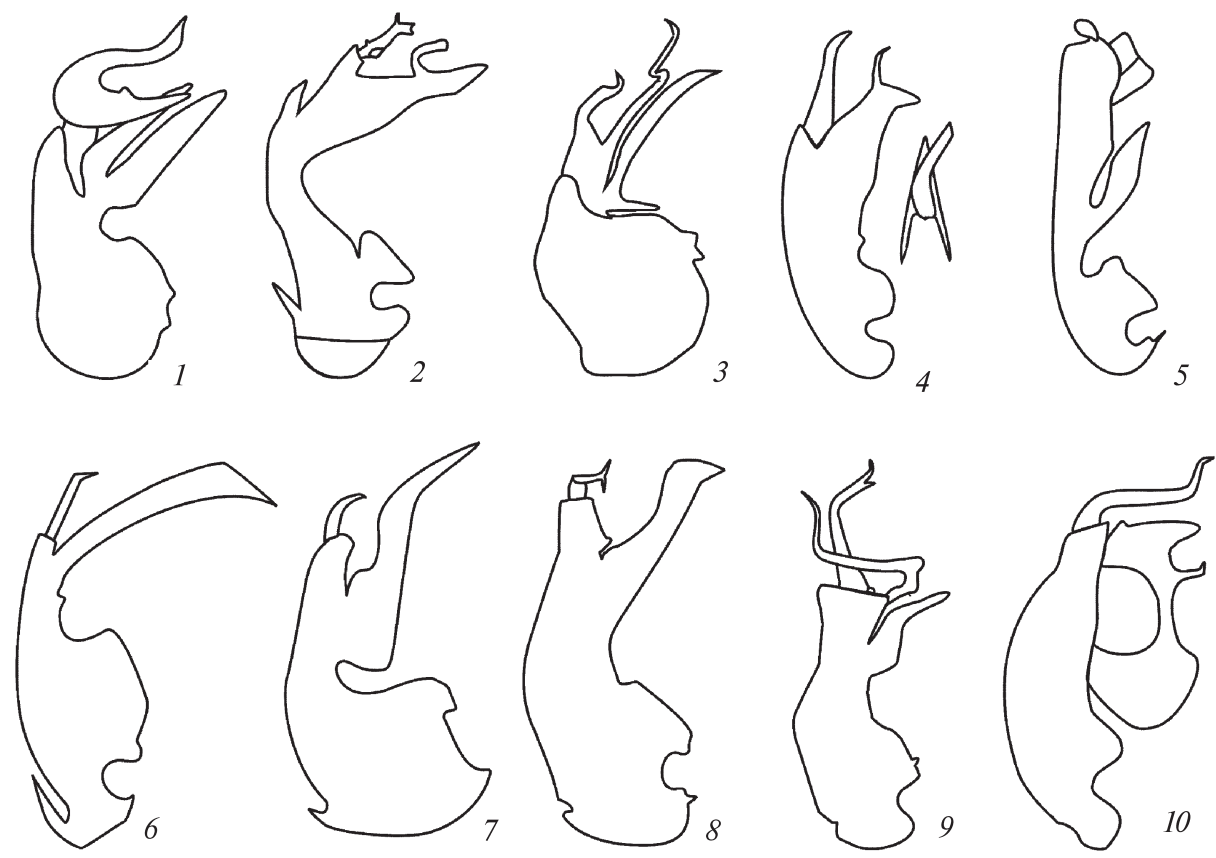

Fig. 2. Aedeagus: $1-$ G. affinis; $2-$ G. bihamata; $3-$ G. boleti; $4-$ G. congrua; $5-$ G. gentilis; $6-$ G. fasciata; $7-$ - . joyi; 8-G. joyioides; 9-G. lucidula; $10-$ G. manca; 1-3, 5-9- redrawn from Seevers, 1951; 4 - redrawn from Strand, $1946 ; 10$ - original.

Рис. 2. Эдеагус: 1 - G. affinis; $2-$ G. bihamata; $3-$ G. boleti; $4-$ G. congrua; $5-$ G. gentilis; $6-$ G. fasciata; $7-$ G. joyi; 8-G. joyioides; $9-$ G. lucidula; $10-$ G. manca; 1-3, 5-9 - по: Seevers, 1951; 4 - по: Strand, 1946; 10 - оригинальный. 
times black. 1st -4 th atennal segments yellow, 5-11th red-brown. Legs yellow. Vertex with 7 or 8 small, round, distinct punctures on each lateral side. Pronotum transverse, widest at base. Middle of pronotum at base with dense, small punctation; some punctures fused and forming shallow, small striae; pronotal disk, in central part, with 2 longitudinal rows, each consisting of 2 or 3 distinct, small, round punctures. Head and pronotum with dense and distinct reticulate microsculpture. Elytra with even, dense, coarse, small punctures. Male: posterior margin of 7 th abdominal tergite medially with one row of longitudinal small striae; 8th abdominal tergite: posterior margin laterally with 2 long processes, weakly pointed and slightly curved inwards; middle with 2 thin, long, apically pointed appendages (fig. 1, 5). Aedeagus (fig. 2, 5).

Bionomics. The species inhabits xylotrophic and terraneous gill-bearing and tubular fungi. It is usually found in large quantities, and sometimes beetles forming large swarms. Adults are active from May to September (Rusch, 1990; Nikitskij et al., 1996).

Distribution. Palearctic species: Europe, Russia (European territory and Siberia), Caucasus (Horion, 1967; Smetana, 2004).

\section{Gyrophaena fasciata (Marsham, 1802)}

Cherkunov, 1889: 159; Roubal, 1930: 418; Bogdanov, 1985; Smetana, 2004: 443; Mateleshko, 2005: 129.

Material examined. Transcarpathian Region: Zhornava, 8 ex., 10.05.2003; Zarichevo, 2 ex., 04.08.2001 (CM); Kyiv: Hydropark, 1 ex., 14.06.2006; Teremki, 13 ex., 06.08.1978; 2 ex., 19.07.1980; Novobelichi, 29 ex., 19.08.1984 (SIZK); Lugansk Region: Stanichno-Luganskiy, 1 ex., 8.07.2008; 2 ex., 20.07.2008 (CG); Lviv Region: Lviv, 2 ex., 10.02.[?]; 1 ex., 10.06.[?](SMNL); Roztochchya, 36 ex., 24.08.1988; 2 ex., 10.06.1990 (SIZK); Ternopil Region: Terebovlya, 13 ex., 4.07; 1 ex., 6.07.[?]; 1 ex., 9.07.[?] (SMNL); Cherkasy Region: Kaniv, 1 ex., 10.09.1987 (SIZK).

Description. Body length 1.8-2.4 mm. Head black. Pronotum dark brown, sometimes brown, with narrow pale brown margin at base and laterally. Elytra yellowbrown with slightly darkened posterior angles. Abdomen yellowish red-brown, 6th and 7 th tergites black. Antennae and legs yellow. Vertex with 8-10 small, round, distinct punctures on each lateral side. Middle and lateral sides of pronotal disc with scattered, small, rounded punctures; pronotum mediobasally with 2 large punctures. Elytra with even, dense, coarse, large punctation. Entire body with dense and distinct reticulate microsculpture. Male: posterior margin of 7th tergite with 1 row of rounded, oblong, large punctures; middle and each lateral side of 8th tergite with 2 large, rounded punctures. Middle of posterior margin of 8 th tergite with shallow incision bordered by 2 short, wide appendages (fig. 1, 6). Aedeagus (fig. 2, 6).

Bionomics. The species inhabits xylotrophic and terraneous gill-bearing and tubular fungi. It is usually found in large quantities and sometimes beetles forming large swarms. Adults are active from April to October (Rusch, 1990; Nikitskij et al., 1996).

Distribution. Palearctic species: Europe, Russia (European territory, East Siberia), Caucasus (Horion, 1967; Smetana, 2004).

Gyrophaena joyi Wendeler, 1924*

Material examined. Volyn Region: Zelene 1 ex., 12.08.1988 (SIZK); Transcarpathian Region: Vorochevo, 1 ex., 29.04.2001; 1 ex., 3.06.2001; 1 ex., 15.07.2007; Nevitske, 4 ex., 15.06.2001 (CM); Kyiv: Golosieve, 7 ex., 09.09.2008; Novobelichi, 8 ex., 19.08.1984 (SIZK); Lugansk Region: Stanichno-Luganskiy, 72 ex., 17.06.2007; 271 ex., 24.06.2007; 13 ex., 26.06.2007; 63 ex., 20.07.2008 (CG); Lviv Region: Roztochchya, 168 ex., 10.06.1990 (SIZK); Cherkasy Region: Kaniv, 200 ex., 10.09.1987 (SIZK); 1 ex., 20.07.2008 (CG); Lukovitse, 9 ex., 04.06.1999 (SIZK).

Des cription. Body length 1.7-2.1 mm. Head black. Pronotum black, sometimes dark brown. Elytra pale brown with slightly darkened posterior angles. 1st-3rd abdom-

* The species first noted in Ukraine. 
inal tergites pale brown, 4-8th black-brown. 1st-4th antennal segments yellow, 5-11th dark brown. Legs yellow. Vertex with 3-5 small, round, faint punctures on each lateral side. Pronotum laterally with sparse, small punctation; middle of pronotum with 2 longitudinal rows of 5 or 6 large, round, distinct punctures each. Elytra with dense, coarse, small punctation. Entire body with dense and distinct reticulate microsculpture. Male: middle of 7th abdominal tergite with 1 row of 6 rounded, oblong, large punctures; 8th abdominal tergite at the middle of posterior margin with 2 large, rounded punctures. Posterior margin of 8th tergite with 2 short, straight, apically pointed, somewhat inward curved appendages (fig. 1, 7). Aedeagus (fig. 2, 7).

Bionomics. The species often inhabits xylotrophic, and sometimes terraneous gillbearing and tubular fungi. It is usually found in large quantitities and sometimes beetles forming large swarms. Adults are active from June to September. (Rusch, 1990; Nikitskij et al., 1996).

Distribution. West Palearctic species: Europe, Russia (European territory) (Horion, 1967; Smetana, 2004). Recorded from Ukraine for the first time.

\section{Gyrophaena joyioides Wüsthoff, 1937*}

Material examined. Volyn Region: Zelene 18 ex., 11.08.1988 (SIZK); Transcarpathian Region: Kvasovo, 1 ex., 28.06.2004; Otok, 28 ex., 5.06.2004; 149 ex., 28.06.2004; Domashinskiy Verh, 1 ex., 26.06.2004; Strichava, 3 ex., 24.08.2001 (CM); Kuziy, 5 ex., 21.09.2006; Velikiy Bichkov, 2 ex., 29.09.2006; Rahiv, 5 ex., 19.05.2002 (CGO); Dubki, 1 ex., 12.09.2004; Nevitske, 22 ex., 15.06.2001; 5 ex., 28.07.2002; 1 ex., 17.07.2004; Orihovitsya, 4 ex., 22.05.2004; 4 ex., 26.05.2002 (CM); Kyiv: Hydropark, 2 ex., 14.06.2006; Teremki, 32 ex., 19.07.1980; Golosieve 14 ex., 09.09.2008 (SIZK); Crimea: Chatirdag, 7 ex., 26.08.1978 (SIZK); Lugansk Region: Gorodishe, 3 ex., 11.06.2009 (CG ); Gostra Mogila, 17 ex., 29.05.2005; 152 ex., 28.05.2007; 5 ex., 13.06.2008; Provalskiy Step, 15 ex., 16.07.2005; 8 ex., 13.07.2008; 283 ex., 14.07.2008; Stanichno-Luganskiy, 3 ex., 27.05.2007; 2 ex., 28.05.2007; 24 ex., 22.07.2007; 9 ex., 25.07.2007; 1 ex., 8.07.2008; 85 ex., 20.07.2008 (CG); Sumy Region: Starogutska area, 35 ex., 21.06.2006 (SIZK).

Description. Body length 1.6-2.2 mm. Head dark brown with pale brown spot in the area of clypeus. Pronotum dark brown, sometimes brown, with narrow pale brown margin at base and laterally. Elytra yellow-brown with slightly darkened posterior angles. Abdomen red-brown, 5th and 6th abdominal tergites dark brown. 1st-4th antennal segments yellow, 5-11th brown. Legs yellow. Vertex with 3-5 small, round, distinct punctures on each lateral side. Antennae: 5th segment smaller and narrower than following segments. Pronotum laterally with sparse, small punctation; middle of pronotum with 2 longitudinal rows of 5 or 6 small, round, distinct punctures each. Elytra with dense, coarse, small punctation. Entire body with dense and distinct reticulate microsculpture. Male: middle of 7th abdominal tergite with 1 row of 6 large, rounded punctures; 8th abdominal tergite: posterior margin with 2 round, small, shallow punctures; middle of posterior margin with wide, shallow incision bordered by 2 short, pointed, smooth, somewhat inward curved appendages (fig. 1, $8 a$ ). Middle of posterior margin of 9th tergite with small, shallow incision bordered by 2 short, apically weakly pointed appendages (fig. 1, $8 \mathrm{~b}$ ). Aedeagus (fig. 2, 8).

Bionomics. The species inhabits xylotrophic and terraneous gill-bearing and tubular fungi. It is usually found in large quantities. Adults are active from June to September. (Rusch, 1990; Nikitskij et al., 1996).

Distribution. West Palearctic species: Europe, Russia (European territory), Caucasus (Horion, 1967; Smetana, 2004). Recorded from Ukraine for the first time.

Gyrophaena lucidula Erichson, 1837

Hochhuth, 1872: 112; Cherkunov, 1889: 159; Jakobson, 1905-1915: 533; Smetana, 2004: 444.

Material examined. Transcarpathian Region: Nevitske, 1 ex., 15.06.2001 (CM); Kyiv: «K.» [Kyiv], 6 ex., undated, (NHMK); Hydropark, 3 ex., 14.06.2006 (SIZK); Lugansk Region: Gostra Mogila, 3 ex., 29.05.2005 (CG); Odesa Region: Troitske, 6 ex., 6.08.2002 (CGO). 
De s cription. Body length 1.0-1.8 mm. Head black. Pronotum black, sometimes dark brown. Elytra yellow-brown with slightly darkened posterior angles. Abdomen black. 1st-4th antennal segments yellow, 5-11th dark brown. Legs yellow. Vertex with 7-9 small, round, distinct punctures on each lateral side. Middle and lateral sides of pronotum with scattered, small, rounded punctures; middle of pronotum with 2 large, round punctures; base of pronotum with dense, small punctures. Middle of each elytron with 1 large dent. Elytra laterally with regular, longitudinal rows of small, scattered, round punctures. Middle of elytron in area of dents without or with weak punctation. Entire body with dense and distinct reticulate microsculpture. Male: posterior margin of 8th abdominal tergite with 2 thin, long, pointed, weakly curved inwards appendages (fig. 1,9). Aedeagus (fig. 2, 9).

Bion omics. The species inhabits xylotrophic fungi. Rare, usually found in small quantities. Adults are active from June to September (Rusch, 1990).

Distribution. West Palearctic species: North Africa (Algeria), Europe, Russia (European territory), Caucasus (Horion, 1967; Smetana, 2004).

\section{Gyrophaena manca Erichson, 1839}

Hochhuth, 1872: 114; Cherkunov, 1889: 159; Jakobson, 1905-1915: 533; Smetana, 2004: 444.

Material examined. Volyn Region: Zelene 20 ex., 11.08 .1988 (SIZK); Dnipropetrovsk Region: Andriyivka, 11 ex., 10.06.2009 (CF); Donetsk Region: Donetsk, 37 ex., 27.08.1999 (SIZK); Kyiv: «K.» [Kyiv], 4 ex., undated, (NHMK); Transcarpathian Region: Domashin, 1 ex., 27.07.2001; Tepla Yama, 1 ex., 30.11.2002; 1 ex., 15.07.2007 (CM); Rahiv, 5 ex., 15.05.2002 (CGO); Nevitske, 6 ex., 15.06.2001; 2 ex., 1.09.2001; 1 ex., 8-14.08.2001; 1 ex., 19.05.2001; 1 ex., 30.08.2003; Orihovitsya, 3 ex., 26.05.2002; İvano-Frankivsk Region: Kremintsi, 1 ex., 3.05.[?](SMNL); Kyiv: Hydropark, 62 ex., 14.06.2006; Novobelichi, 10 ex., 23.05.1985 (SIZK); Lugansk Region: Diakove, 1 ex., 24-25.05.1999 (CK); Gorodishe, 268 ex., 11.06.2009 (CG); Gostra Mogila, 174 ex., 29.05.2005; 621 ex., 28.05.2007; 358 ex., 13.06.2008; Provalskiy Step, 8 ex., 13.07.2008; StanichnoLuganskiy, 1 ex., 29.04.2007; 32 ex., 13.05.2007; 17 ex., 19.05.2007; 256 ex., 21.05.2007; 16 ex., 22.05.2007; 16 ex., 25.05.2007; 18 ex., 26.05.2007; 569 ex., 27.05 2007; 122 ex., 27.05.2007; 28 ex., 28.05.2007; 6 ex., 3.06.2007; 183 ex., 10.06.2007; 232 ex., 10.06.2007; 15 ex., 17.06.2007; 505 ex., 24.06.2007; 17 ex., 26.06.2007; 94 ex., 25.07.2007; 23 ex., 8.07.2008; 2 ex., 20.07.2008 (CG); Odesa Region: Troitske, 1 ex., 6.08.2002 (CGO); Sumy Region: Starogutska area, 186 ex., 21.06.2006 (SIZK); Chernivtsi Region: «Bukowina, Cernowitz» [Chernivtsi], 5 ex., undated (ZMTSNU).

Description. Body length 1.3-1.6 mm. Head black. Pronotum, elytra and abdomen dark brown, sometimes pale brown. Antennae and legs yellow, sometimes pale brown. Vertex with 10 or more small, round, distinct punctures on each half.Entire surface of pronotum with even punctation of numerous small, round, scattered, numerous punctures. Elytra with even small punctation. Entire body with dense and distinct reticulate microsculpture. Male: posterior margin of 8th tergite with 2 thin, long, pointed, weakly curved inwards appendages (fig. 1, 10). Aedeagus (fig. 2, 10).

Bion omics. The species inhabits only xylotrophic fungi. Adults are active from June to September. (Rusch, 1990; Nikitskij et al., 1996).

Distribution. Palearctic species: Europe, Russia (European territory and Siberia), Caucasus (Horion, 1967; Smetana, 2004).

\section{Gyrophaena minima Erichson, 1837}

Hochhuth, 1872: 112; Cherkunov, 1889: 159; Jakobson, 1905-1915: 533; Smetana, 2004: 444; Mateleshko, 2005: 129 .

Material examined. Transcarpathian Region: Zhornava, 4 ex., 10.05.2003; Strichava, 8 ex., 24.08.2001; Vorochevo, 3 ex., 3.06.2001; Zarichevo, 5 exs., 20.05.2001; 6 ex., 20.08.2001; 9 ex., 15.07.2007; 11 ex., 04.08.2001; Dubki, 1 ex., 12.09.2004; Nevitske, 136 ex., 15.06.2001; 8 ex., 1.09.2001; 3 ex., 19.05.2002; 1 ex., 8-14.08.2001; 5 ex. , 28.07.2002; 2 ex., 30.08.2003; Onokivtsi, 4 ex., 19-24.07.2001; Orihovitsya, 3 ex., 26.05.2002 (CM); Kyiv: «K.» [Kyiv], 1 ex., (NHMK); Golosieve, 2 ex., 09.09.2008; Novobelichi, 5 ex., 14.07.1985; 7 ex., 12.08.1984 (SIZK); Cherkasy Region: Lukovitse, 1 ex., 04.06.1999 (SIZK); Lviv Region: Lviv, 1 ex., 10.02.[?] (SMNL); Roztochchya, 5 ex., 24.08.1988 (SIZK). 
Description. Body length 1.0-1.4 mm. Head dark brown with pale brown spot on and around clypeus. Pronotum pale brown, sometimes yellow. Elytra yellow or yellow-brown. Abdomen yellow-brown, 6th and 7th abdominal tergites dark brown. Antennae and legs yellow. Vertex with 5-7 small, round, distinct punctures on each lateral side.Entire surface of pronotum with even punctation of numerous small, round, scattered, numerous punctures; pronotum at base with dense, small punctures. Elytra with even small punctation. Entire body with dense and distinct reticulate microsculpture. Male: posterior margin of 7 th abdominal tergite medially with one row of longitudinal, long and short striae; 8th tergite: medio-basally with 2 large, oblong striae; in middle of posterior margin with two short, pointed appendages, and laterally, with 2 thin, long, pointed, weakly inward curved appendages (fig. 3,1). Aedeagus (fig. 4, 1).

Bion omics. The species mainly inhabits xylotrophic and some terraneous gill-bearing fungi. Adults are active from June to September (Rusch, 1990; Nikitskij et al.,1996).

Distribution. Palearctic species: Europe, Russia (European territory and Siberia), (Horion, 1967; Smetana, 2004).
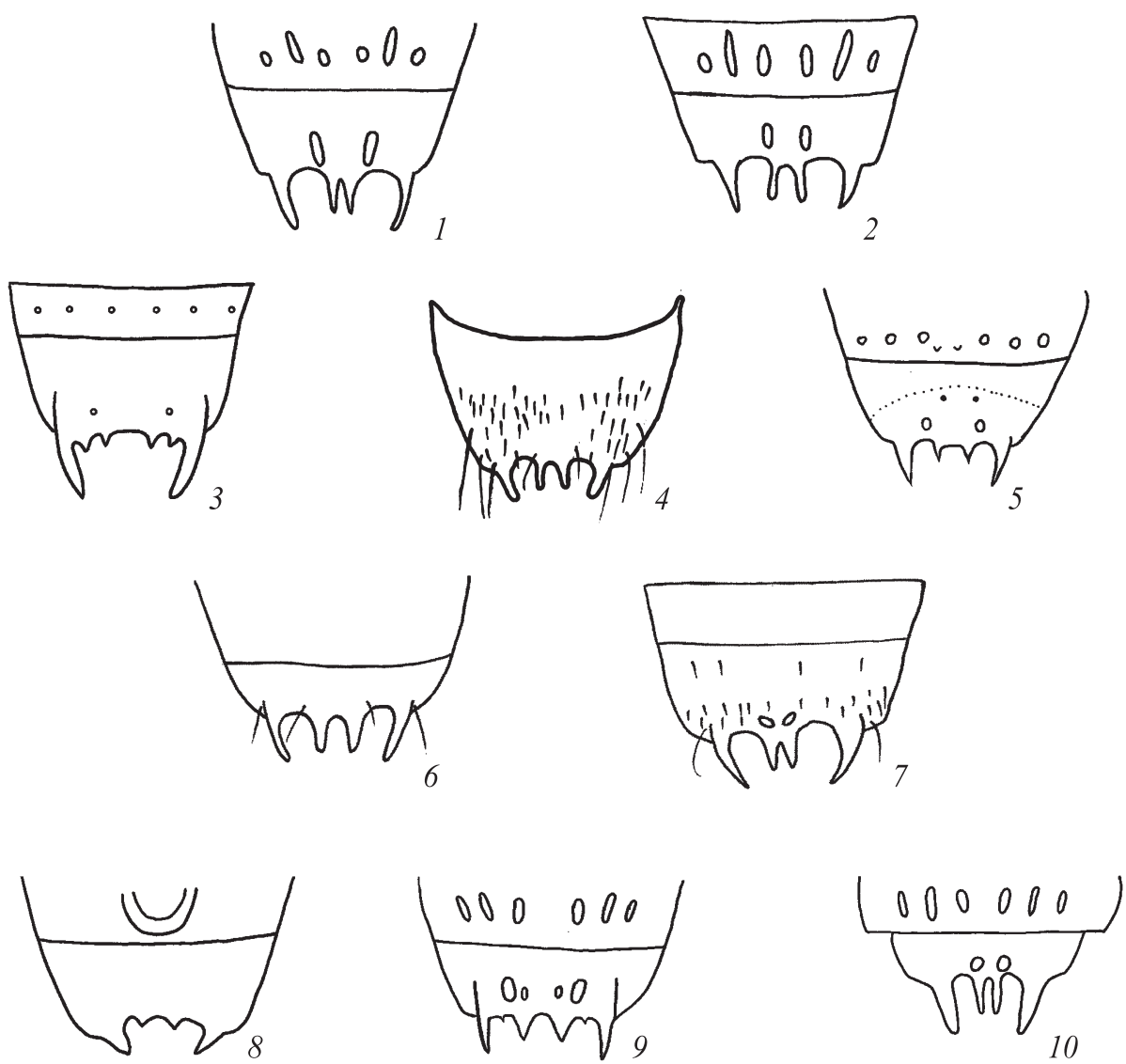

Fig. 3. 7-8th abdominal tergites of male: $1-$ G. minima; $2-$ G. nana; $3-$ G. nitidula; $4-$ G. orientalis; $5-$ G. polita; $6-G$. poweri; $7-G$. pseudonana; $8-G$. pulchella; $9-$ G. strictula; $10-G$. williamsi; $1-3,5$, 8-9 - redrawn from Wüsthoff, 1937; 4, 6, 7 - original; 10 - redrawn from Scheerpeltz, Höfler, 1948.

Рис. 3. Седьмой и восьмой тергиты самца: $1-$ G. minima; $2-$ G. nana; $3-$ G. nitidula; $4-$ G. orientalis; 5 - G. polita; $6-$ G. poweri; $7-$ G. pseudonana; $8-$ G. pulchella; $9-$ G. strictula; $10-$ G. williamsi; 1-3, 5, 8-9 - по: Wüsthoff, 1937; 4, 6, 7 - оригинальные; 10 - по: Scheerpeltz, Höfler, 1948. 
Gyrophaena nana (Paykull, 1800)

Hochhuth, 1872: 112; Cherkunov, 1889: 159; Jakobson, 1905-1915: 533; Smetana, 2004: 444.

Material examined. Volyn Region: Zelene, 2 ex., 12.08.1988 (SIZK); Transcarpathian Region: Nevitske, 1 ex., 10.08.1998 (CM); Kyiv: «K.» [Kyiv], 2 ex., undated (NHMK); Teremki, 17 ex., 19.07.1980; Novobelichi, 5 ex. 19.08.1984 (SIZK); Crimea: Chatirdag, 1 ex., 26.08.1978 (SIZK); Lviv Region: Lviv, 1 ex., 12.04.1917; 1 ex., 19.02.[?]; 1 ex., 5.03.[?] (SMNL); Ternopil Region: Terebovlya, 13 ex., 9.08.[?] (SMNL).

Description. Body length $1.8-2.3 \mathrm{~mm}$. Head black. Pronotum black, sometimes dark brown; with narrow pale brown margin at base and laterally. Abdomen pale brown; $5-7$ th tergites black or dark brown. Antennae and legs pale brown. Vertex with 6 or more small and also one large, round, distinct punctures on each lateral side. Antennae: 4th antennal segment somewhat wider than previous; 5th almost square; 6-10th each, slightly widened apicad; 10th somewhat wider than previous. Pronotum laterally with sparse, small punctation; middle of pronotum with 2 longitudinal, discontinuous in centre, admedian rows, each with 3 or 4 small, round, distinct punctures; pronotum at base with dense, small punctures. Elytra, except narrow smooth band near suture, with even, rough and small punctation. Head, pronotum and elytra smooth without reticulate microsculpture. Male: posterior margin of 7th abdominal tergite medially with a row of oblong, longer and shorter striae; 8th tergite: medially with 2 oblong but short striae near posterior margin; posterior margin with 2 short, thin, pointed, weakly inward curved appendages, medially with pair of appendages of almost same length as lateral ones (fig. 3, 2). Aedeagus (fig. 4, 2)

Bion omics. The species inhabits xylotrophic and terraneous gill-bearing fungi. It is usually found in large quantities, but not forming large swarms. Adults are active from June to September (Rusch, 1990; Nikitskij et al., 1996).

Distribution. Widely distributed in the Holarctic: Europe, Russia (European territory, Siberia and Russian Far East), Caucasus; North America (Seevers, 1951; Horion, 1967; Smetana, 2004).

\section{Gyrophaena nitidula (Gyllenhal, 1810)}

Hochhuth, 1872: 112; Cherkunov, 1889: 159; Jacobson, 1905-1915: 533; Smetana, 2004: 445; Mateleshko, 2005: 129; Mateleshko, 2007: 185.

Material examined. Transcarpathian Region: Zhornava, 2 exs., 31.05.2003; Stavne, 1 ex., 24.05.2003; Buzhora, 2 ex., 1.08.2002; Tovstiy Grun, 2 ex., 08.06.1999; Kamjanitsya, 1 ex., 4.05.2003; Nevitske, 3 ex., 17.07.1999; Siruy potik, 1 ex., 22.06.2003 (CM).

Description. Body length 2.6-3.0 mm. Head dark brown, sometimes black. Pronotum black or dark brown. Elytra reddish-yellow, sometimes pale brown; with slightly darkened posterior angles. Abdominal tergites usually black or dark brown; posterior margin of each tergite pale brown. Antennae and legs yellow. Vertex with some small, round, distinct punctures on each lateral side. Antennae long, thin; $10^{\text {th }}$ segment weakly widened towards apex, somewhat wider and longer than previous segments, parallelsided; 1.5 times as wide as long. Pronotum smooth, glossy. Elytra with even, dense, small punctures; elytral posterior angles with large punctures. Male: 7th tergite: medially of with 1 longitudinal row of scattered, round, small punctures; at posterior margin with 1 transverse row of dense, small punctures. 8th tergite at middle near base with 2 small, round punctures; its posterior margin with 2 long, pointed, somewhat curved inwards appendages laterally and with 4 short, pointed teeth medially (fig. 3, 3). Aedeagus (fig. 4, 3).

Bion omics. Ecology and seasonal activity unknown.

Distribution. Palearctic species: East and South Europe, Turkey, Russia (European territory, Siberia) (Horion, 1967; Smetana, 2004). 

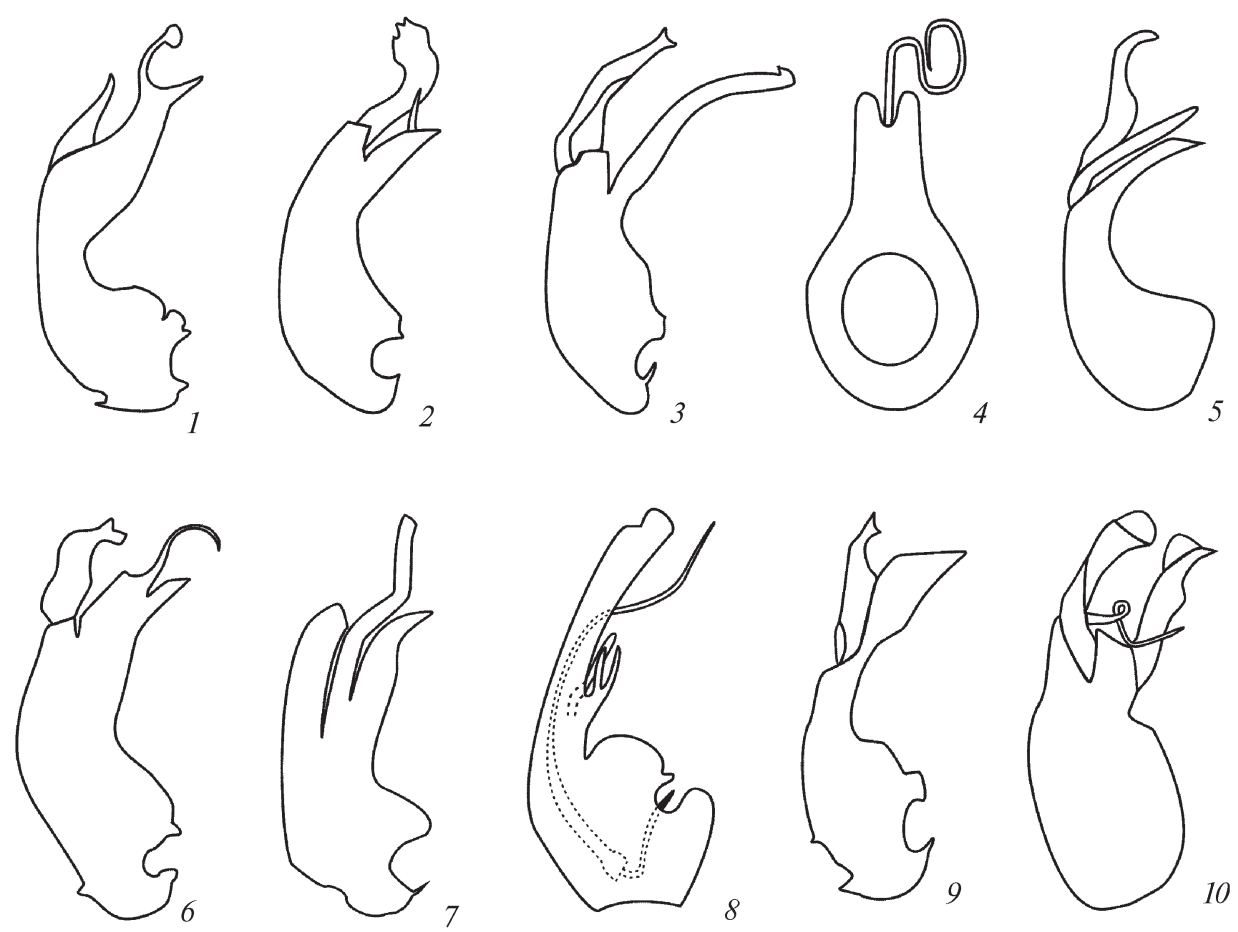

Fig. 4. Aedeagus: $1-$ G. minima; $2-$ G. nana; $3-$ G. nitidula; $4-$ G. orientalis; $5-$ G. polita; $6-G$. poweri; $7-$ G. pseudonana; $8-G$. pulchella; $9-$ G. strictula; $10-G$. williamsi; 1-3, 6, 8-9- redrawn from Seevers, 1951; 7 - original; 4- redrawn from Strand, 1968; 5- redrawn from Wüsthoff, 1937; 10 - redrawn from Scheerpeltz, Höfler, 1948.

Рис. 4. Эдеагус: $1-$ G. minima; $2-$ G. nana; $3-$ G. nitidula; 4-G. orientalis; $5-$ G. polita; 6-G. poweri; $7-$ G. pseudonana; $8-$ G. pulchella; $9-$ G. strictula; $10-$ G. williamsi; 1-3, 6, 8-9- по: Seevers, 1951; 7 - оригинальный; 4 - по: Strand, 1968; 5- по: Wüsthoff, 1937; 10 - по: Scheerpeltz, Höfler, 1948.

Gyrophaena orientalis A. Strand, 1938*

Material examined. Kyiv: Novobelichi, 7 ex., 14.07.1985 (SIZK).

Description. Body length 1.7-2.0 mm. Head dark brown. Pronotum brown. Elytra pale brown; posterior angles and base with 2 ( 1 on each elytron) triangular, apically pointed, dark brown spots. Abdomen pale brown, 6th and 7th tergites dark brown or black. Antennae pale brown, 1st antennal segment yellow. Legs yellow. Vertex with 5-7 small, round, distinct punctures on each lateral side. 5th segment of antennae strongly transverse. Pronotum smooth, glossy; laterally with sparse, small punctation; with 2 admedian rows, each with 6-7 large, round, distinct punctures; base with dense, small punctures; posterior angles weakly rounded; 1.5 times as wide as long; with or without faint reticulate microsculpture. Elytra with sparse, small punctation and small, scattered, thin hairs; 1.5 times as long as pronotum; with distinct reticulate microsculpture, gradually weakening towards suture. Male: posterior margin of 7 th abdominal tergite medially with a row of oblong, longer and shorter striae; 8th tergite: posterior margin with 2 long, pointed, inward curved appendages; medially with 2 short, thin, pointed appendages and with 2 small, pointed teeth laterally from medial appendages (fig. 3, 4). Aedeagus (fig. 4, 4).

Bionomics. The species inhabits xylotrophic and terraneous gill-bearing fungi (Nikitskij et al., 1996). It was found in July, but the phenology is unknown.

Distribution. Known from several countres of Europe (Finland, Slovakia, Czech Republic), as well as from the North of European Russia. Specimens newly found in Kyiv represent the southernmost record of this species. Recorded from Ukraine for the first time. 
Gyrophaena poweri Crotch, 1866

Hochhuth, 1872: 112; Cherkunov, 1889: 159; Jakobson, 1905-1915: 533; Smetana, 2004: 445.

Material examined. Transcarpathian Region: Vorochevo, 1 ex., 3.06.2001; Orihovitsya, 1 ex. 22.05.2004 (CM).

Des cription. Body length 1.5-2 mm. Head dark brown. Pronotum brown. Elytra reddish-brown; their posterior angles and apical part with 2(one on each elytron) triangular, apically pointed, brown spots. Abdomen reddish-brown, 6th tergite dark brown. Antennae and legs yellow. Vertex with some small, round, distinct punctures and one larger round puncture on each lateral side. Entire surface of pronotum with even punctation of numerous, small, round, scattered, punctures; at base and laterally with some larger, round punctures. Elytra with dense, coarse, small punctation. Entire body with dense and distinct reticulate microsculpture. Male: posterior margin of 7 th abdominal tergite medially with a row of oblong, longer and shorter striae; 8th tergite: at base near middle with 2 large punctures; posterior margin with 2 long, thin, pointed, weakly inward curved appendages; medially with 2 thin, long, pointed appendages of about same length as lateral ones, each of which with 2 short, pointed teeth (fig. 3, 6). Aedeagus (fig. 4, 6).

Bi on o mics. The species mainly inhabits xylotrophic and some terraneous gill-bearing fungi. Adults are active from May to September (Rusch, 1990; Nikitskij et al. , 1996).

Distribution. West Palearctic species: Europe, Russia (European territory) (Horion, 1967; Smetana, 2004).

Gyrophaena pulchella Heer, 1839

Hochhuth, 1872: 112; Cherkunov, 1889: 159; Jakobson, 1905-1915: 533; Smetana, 2004: 445.

Material examined. Transcarpathian Region: Stavne, 1 ex., 10.09.1998 (CM); Lviv Region: Roztochchya, 92 ex., 24.08.1988 (SIZK).

Description. Body length $2.3-2.8 \mathrm{~mm}$. Head black. Pronotum dark brown, sometimes brown. Elytra pale brown; posterior angles darkened. Abdomen reddishbrown, sometimes pale brown. Antennae and legs yellow. Entire surface of head with even, sparse, small punctation. Antennae: 5-10th segments almost of quadrate shape, each slightly widened apicad. Entire surface of pronotum with even, small punctation of round, scattered, not numerous punctures; at base and medially with some larger punctures. Elytra with even, rough and small punctures. Head and pronotum with faint reticulate microsculpture. Middle of posterior margin of 8th tergite with wide incision bordered by 2 short, wide, apically weakly pointed, curved inwards appendages and with 2 short, pointed teeth (fig. 3, 8). Aedeagus (fig. 4, 8).

Bionomics. The species inhabits on xylotrophic and some terraneous gill-bearing fungi. Adults are active from July to October (Rusch, 1990; Nikitskij et al., 1996).

Distribution. Holarctic species: Europe, Russia (European part and Siberia), Caucasus; North America (Horion, 1967; Smetana, 2004).

Gyrophaena pseudonana Strand, 1939*

Material examined. Lugansk Region: Stanichno-Luganskiy, 1 ex., 30.04.2007 (CG).

Description. Body length 1.8-2.2 mm. Head black. Pronotum black, with narrow pale brown margin at base and laterally. Elytra pale brown with slightly darkened posterior angles. Abdomen pale brown, sometimes brown, 6th and 7th abdominal tergites black. 1st -4 th antennal segments yellow, 5-11th pale brown. Head glossy with dense and distinct reticulate microsculpture; vertex with 10 or more small, round, faint punctures on each lateral side. Antennae: 5-10th antennal segments cylindrical. Pronotum glossy, without reticulate microsculpture; laterally with sparse, fine punctation; middle of prono- 
tum with 2 admedian rows, each with 6 or 7 small, round, distinct punctures; pronotum at base with dense, small punctuation. Elytra with even, dense, coarse, large punctures. Male: posterior margin of 7 th abdominal tergite medially with a row of longitudinal, long and short striae; 8th abdominal tergite: medio-apically with 2 small, rounded punctures; posterior margin with 2 short, thin, pointed, weakly inward curved appendages, medially with apically bifurcated appendage of same length as lateral appendages (fig. 3, 7). Aedeagus (fig. 4, 7).

Bion omics. The species inhabits xylotrophic and some terraneous gill-bearing fungi Adults are active from April to October (Rusch, 1990).

Distribution. Central and southern Europe (Smetana, 2004). Recorded from Ukraine for the first time.

\section{Gyrophaena williamsi A. Strand, 1935*}

Material examined. Kyiv: Novobelichi, 1 ex., 14.07.1985 (SIZK); Cherkasy Region: Kaniv, 6 ex., 10.09.1987 (SIZK).

Description. Body length $1.7-2.0 \mathrm{~mm}$. Head black. Pronotum pale brown. Elytra pale brown; posterior angles and apical part with 2 (one on each elytron) triangular, apically pointed, brown spots. Abdomen pale brown, 6th tergite brown. Antennae and legs yellow. Head glossy; vertex with 8 or 9 small, round, distinct punctures on each half. Pronotum glossy; laterally with sparse, small punctation; with 2 admedian rows of 4 or 5 small, round, distinct punctures each. Head and pronotum with dense and distinct reticulate microsculpture. Elytra with even, rough and small punctation except near suture. Male: posterior margin of 7th abdominal tergite with a row of oblong but short striae; 8th abdominal tergite: medio-apically with 2 oblong, short striae; posterior margin with 2 long, thin, smooth, appendages somewhat inward curved, medially with 2 thin, long, apically pointed appendages (fig. 3, 10). Aedeagus (fig. 4, 10).

Bionomics. According to Rusch (1990), the species prefers the fungus Tricholomopsis rutilans (Schaeff.) Singer (1939) (Rusch, 1990).

Distribution. West Palearctic species: Europe, Russia (Moscow Region) (Horion, 1967; Nikitskij et al., 1996; Smetana, 2004). Recorded from Ukraine for the first time.

\section{Gyrophaena boleti (Linnaeus, 1758)}

Hochhuth, 1872: 112; Cherkunov, 1889: 159; Jakobson, 1905-1915: 533; Smetana, 2004: 442.

Material examined. Kyiv: «K.» [Kyiv], 2 ex., undated, (NHMK).

Description. Body length $0.7-1.3 \mathrm{~mm}$. Head and pronotum black; elytra black, sometimes dark brown. Abdomen black, 7th and 8th tergites pale yellow. Entire surface of head and pronotum with even, sparse, small punctures. Pronotum transverse, 1.3-1.4 times as wide as long, widest at middle. Elytra slightly wider than pronotum, with even, thick, rough and small punctation. Abdomen and elytra parallel-sided. Entire body with dense and distinct reticulate microsculpture. Male: middle of posterior margin of 8th tergite with shallow incision bordered on each side by 2 short, apically pointed appendages; middle of incision with 2 short teeth (fig. 1, 3). Aedeagus (fig. 2, 3).

B i o nomics. The species inhabits Fomiapexsis pinicola (Sw.) P. Karst. (1881). It is usually found in large quantities. Adults are active from May to September (Rusch, 1990; Nikitskij et al., 1996).

Distribution. Palearctic species: Europe, Russia (European territory and Siberia), Turkey, Kazakhstan (Horion, 1967; Smetana, 2004). 
Gyrophaena polita (Gravenhorst, 1802)

Hochhuth, 1872: 115; Cherkunov, 1889: 159; Jakobson, 1905-1915: 533; Smetana, 2004: 446.

Material examined. Kyiv: «K.» [Kyiv], 1 ex., undated (NHMK).

Description. Body length 1.2-1.4 mm. Body black, sometimes dark brown, glossy. Antennae and legs yellow, sometimes pale brown. Entire surface of head with even, sparse, small punctation. Surface of pronotum with even, small punctation of numerous round, scattered punctures. Posterior angles of elytra with dense, rough punctation. Head and pronotum without reticulate microsculpture; abdomen and elytra with weak reticulate microsculpture. Male: posterior margin of 7 th tergite with a longitudinal row of scattered, round, small punctures. 8th tergite: medio-basally with 2 oval, oblong, small punctures; posterior margin with 2 long, thin, pointed, nearly parallel appendages; medially with 2 short, thin, pointed appendages (fig. 3, 5). Aedeagus (fig. 4, 5).

Bi on omics. Ecology and seasonal activity are unknown.

Distribution. Probably wide-spread Palearctic species; known from Central and South Europe, and Siberia (Horion, 1967; Smetana, 2004).

\section{Gyrophaena strictula Erichson, 1839}

Hochhuth, 1872: 113; Cherkunov, 1889: 159; Jakobson, 1905-1915: 533; Smetana, 2004: 446; Mateleshko, 2005: 129 .

Material examined. Transcarpathian Region: Vorochevo, 1 ex., 28.07.2001; Nevitske, 1 ex., 17.07.2004; 1 ex. 8-14.08.2001; 1 ex., 28.07.2002 (CM); Kyiv: «K.» [Kyiv], 3 ex., undated (NHMK); Lugansk Region: Gostra Mogila, 1 ex., 28.05.2007; Stanichno-Luganskiy, 2 ex., 30.04.2007 (CG); Chernivtsi Region: «Bukowina, Cernowitz» [Chernivtsi], 10 ex., undated (ZMTSNU).

Des cription. Body length 1.3-1.6 mm. Head, pronotum and elytra dark brown, sometimes black. 1st-5th abdominal tergites reddish-brown, 6th and 7th dark brown. Antennae and legs pale brown. Vertex with some small, round, faint punctures. Pronotum with even, small punctation of round, scattered, not numerous punctures. Elytra with even, thick and small punctation. Entire body with dense and distinct reticulate microsculpture. Male: posterior margin of 7 th tergite with 1 row of longitudinal long and short striae; 8th tergite: medio-basally with 2 oblong, small punctures; posterior margin with 2 long, thin, pointed, smooth, somewhat curved inwards appendages; middle of posterior margin with 2 short, pointed teeth (fig. 3,9). Aedeagus (fig. 4, 9).

Bionomics. The species inhabits xylotrophic fungi. Adults are active from April to October (Rusch, 1990; Nikitskij et al., 1996).

Distribution. West Palearctic species: Europe, Russia (European territory, Western Siberia) (Horion, 1967; Smetana, 2004).

Key to Gyrophaena subgenera and species of Ukrainian fauna

Таблица для определения подродов и видов рода Gyrophaena фауны Украины

1 (23). Head strongly transverse, with large strongly convex eyes; abruptly and strongly narrowed behind eyes; head contour as inverted trapezoid.

2

2 (4). Antennae long, filiform, slender; 1st and 3th antennal segments as thin and as long as rest of segments; 4th segment small and short; 5-10th segments weakly widened apicad.

Subgenus Leptarthrophaena Sheerpeltz, 1948

3 (3). Pronotum dark brown, weakly rounded at base, widest at base. Elytra with even, dense, coarse, large punctation. Entire body with faint, reticulate microsculpture. 7th and 8th abdominal tergites as shown in fig. 1, 1. Aedeagus as shown in fig. 2, 1. Body length $1.7-2.3 \mathrm{~mm}$. ........................... G. affinis

4 (2). Antennae short, markedly thickened; 5-9th antennal segment strongly widened apicad; 10th segment at most weakly widened apicad, with almost parallel sides, 1.5 times as wide as long. ............... 5

Subgenus Gyrophaena Mannerheim, 1830

5 (6). Pronotum black, at base and posterior angles strongly rounded. Elytra with even, dense, coarse, small punctures; elytral posterior angles with large punctures. Head and pronotum smooth, glossy, without 
reticulate microsculpture; elytra with reticulate microsculpture. 7 th and 8 th abdominal tergite as shown in fig. 3, 3. Aedeagus as shown in fig. 4, 3. Body length $2.5-3.0 \mathrm{~mm}$. ......................... G. nitidula

6 (5). Pronotum dark brown, sometimes brown; wider at anterior margin than at base; posterior angles weakly rounded. Head and pronotum with faint, reticulate microsculpture. Elytra with even, dense and small punctures. Antennae long. 7th and 8th tergites as shown in fig. 3, 8. Aedeagus as shown in fig. 4, 8. Body length $2.3-2.8 \mathrm{~mm}$.

G. pulchella

7 (8). Pronotum black, sometimes dark brown; with narrow pale brown margin at base and laterally; posterior angles strongly rounded. Elytra, except narrow smooth band near suture, with even thick, rough and small punctuation. Vertex with 6 or more small and also 1 large, round, distinct punctures on each lateral side. Head, pronotum and elytra smooth, without reticulate microsculpture. 7th and 8th abdominal tergite as shown in fig. 3, 2. Aedeagus as shown in fig. 4, 2. Body length $1.8-2.3 \mathrm{~mm}$...

8 (7). Pronotum dark brown, not bordered; posterior angles weakly rounded. Elytra with denser, rougher and deeper punctation; at middle and near 1 suture with punctation of single punctures or without punctation. Vertex with 10 or more small, round, faint punctures on each lateral side. Head glossy with dense and distinct reticulate microsculpture; pronotum smooth, without reticulate microsculpture. 7 th and 8 th abdominal tergites as shown in fig. 3, 7. Aedeagus as shown in fig. 4, 7. Body length $1.8-2.2 \mathrm{~mm}$. ................................................................................................... G. pseudonana

9 (22). Head black, pronotum dark brown, not bordered at base. Pronotum; distinctly convex; posterior angles weakly rounded; at base with dense, small punctations; middle with 2 longitudinal rows of 2 or 3 punctures. Elytra with even, dense, coarse, small punctures. Head and pronotum with dense and distinct reticulate microsculpture. 7 th and 8 th abdominal tergites as shown in fig. 1, 5. Aedeagus as shown in fig. 2, 5. Body length 2-2.4 mm. G. gentilis

10 (11). Head dark brown, pronotum brown, elytra and abdomen reddish-brown, $6^{\text {th }}$ abdominal tergite dark brown. Entire surface of pronotum with even, small, scattered, numerous punctures. Elytra with dense, coarse, small punctation. Entire body with dense and distinct reticulate microsculpture. Antennae and legs yellow. 7 th and 8 th abdominal tergites as shown in fig. 3, 6. Aedeagus as shown in fig. 4, 6. Body length $1.5-2 \mathrm{~mm}$.

G. poweri

11 (10). Head, pronotum and abdomen black, glossy; elytra yellow-brown with slightly darkened posterior angles. Middle and each lateral side of pronotum with scattered, small, rounded punctures; middle of pronotum with 2 large, round punctures; base of pronotum with dense, small punctures. Entire body with dense and distinct reticulate microsculpture. 1-4th antennal segments yellow; 5-11th dark brown. Legs yellow. 7th and 8th abdominal tergites as shown in fig. 1, 9. Aedeagus as shown in fig. 2, 9. Body length $1.0-1.8 \mathrm{~mm}$.

G. lucidula

12 (13). Head, pronotum, elytra and abdomen dark brown, sometimes black; antennae and legs yellow. Elytra with thick, rough and small punctation. Vertex with 10 or more small, round, distinct punctures on each side. Pronotum with even, sparse and small punctation. Entire body with dense and distinct reticulate microsculpture. 7th and 8th abdominal tergites as shown in fig. 1, 10. Aedeagus as shown in fig. 2, 10. Body length 1.3-1.6 mm.

G. manca

13 (12). Head dark brown, pronotum pale brown, sometimes yellow, elytra yellow-brown, abdomen yellowbrown. 6th and 7th abdominal tergites dark brown, antennae and legs yellow. Vertex with 5 or 7 small, round, distinct punctures on each lateral side. Entire surface of pronotum with even, small punctation of round, scattered, numerous punctures; pronotum at base with dense, small punctures. Entire body with dense and distinct reticulate microsculpture. 7th and 8th abdominal tergites as shown in fig. 3 , 1. Aedeagus as shown in fig. 4, 1. Body length $1.0-1.4 \mathrm{~mm}$. ........................................ G. minima

14 (15). Head black, pronotum and abdomen pale brown, elytra yellow-brown; at base with large, pointed to apex, dark spots. 6th tergite somewhat darkened. Vertex with 8 or 9 small, round, distinct punctures on each half. Pronotum glossy; laterally with sparse, small punctation; at middle with 2 longitudinal rows of 4 or 5 small, round, distinct punctures each. Head and pronotum with dense and distinct reticulate microsculpture. 7 th and 8 th tergites as shown in fig. 3, 10. Aedeagus as shown in fig. 4, 10. Body length $1.6-2.3 \mathrm{~mm}$. ......................................................................................... G. williamsi

15 (14). Head and pronotum brown, elytra yellow-brown; posterior angles with dark punctures. Vertex with 5 or 7 small, round, distinct punctures on each lateral side. Pronotum smooth, glossy; laterally with sparse, small punctation; at middle with two longitudinal rows, each with 6 or 7 large, round, distinct punctures; base with dense, small punctures. Elytra with dense, small, round punctation; microsculpture appreciably weakening towards suture. 7 th and 8th abdominal tergites as shown in fig. 3, 4. Aedeagus as shown in fig. 4, 4. Body length 1.7-2 mm.

G. orientalis

16 (19). Pronotum strongly convex, dark brown; at base without light margin. .................................. 17

17 (18). Head black, elytra pale brown and with strongly darkened posterior angles. 1-3th abdominal tergites brown. 4-8th black-brown. Pronotum laterally with sparse, small punctation; at middle with 2 longitudinal rows of 5 or 6 large, round, distinct punctures each. Elytra with dense, coarse, small punctation. 7th and 8th abdominal tergites as shown in fig. 1, 7. Aedeagus as shown in fig. 2, 7. Body length $1.7-2.1 \mathrm{~mm}$. G. joyi

18 (17). Head dark brown, pronotum and abdomen reddish-brown; pronotum as base with narrow pale margin; elytra yellow-brown; posterior angles with small, dark spots. Pronotum laterally with sparse, small 
punctation; medially with 2 longitudinal rows of 5 or 6 small, round, distinct punctures each. Elytra with dense, coarse, small punctation. $7-9$ th abdominal tergites as shown in fig. $1,8 a$, 8 b. Aedeagus as shown in fig. 2, 8. Body length $1.6-2.2 \mathrm{~mm}$.

G. joyioides

19 (16). Pronotum flat, dark brown; base and lateral sides with pale brown margin. ............................ 20

20 (21). Penultimate segment of antenna strongly transverse. Head black. Abdomen yellow-red-brown; 6th and 7 th tergites black. Vertex with 8 or 10 small, round, distinct punctures on each lateral side. Middle and lateral sides of pronotum with scattered, small, rounded punctures; pronotum mediobasally with 2 large punctures. Entire body with dense and distinct reticulate microsculpture. 7th and 8th abdominal tergites as shown in fig. 1, 6. Aedeagus as shown in fig. 2, 6. Body length $1.8-2.4 \mathrm{~mm}$.

G. fasciata

21 (20). Penultimate segment of antenna weakly transverse with almost parallel sides. Middle of pronotum with 2 longitudinal rows of 3 or 4 large, round, distinct punctures each. Elytra with dense, coarse, small punctation. Abdomen yellow-red-brown; 6th tergite black. Head and pronotum with dense and distinct reticulate microsculpture. 7 th and 8 th abdominal tergites as shown in fig. 1, 2. Aedeagus as shown in fig. 2, 2. Body length $1.5-2.1 \mathrm{~mm}$.

G. bihamata

22 (9). Head black, mat; pronotum dark brown, lustrous; laterally and at base bordered by pale brown margin. Abdomen yellow-brown; 5-7th tergites black. Middle of pronotum with 2 longitudinal rows of 6 or 7 large, clearly marked punctures. Elytra with dense, rough and small punctation. Pronotum and abdomen with dense and distinct reticulate microsculpture. 7 th and 8 th abdominal tergites as shown in fig. 1, 4. Aedeagus as shown in fig. 2, 4. Body length $1.7-2.2 \mathrm{~mm}$. G. congrua

23 (1). Head somewhat widened, with weakly convex eyes, gradually narrowed basad behind eyes. ...... 24

24 (26). Pronotum with even, dense punctation of round, small punctures; middle without longitudinal row of large punctures.

Subgenus Agaricophaena Reitter, 1908

25 (25). Abdomen black; 7th and 8th tergites pale yellow. Head and pronotum black, elytra black-brown. All body with even, sparse, small punctures. Elytra wider than pronotum. 7th and 8th abdominal tergites as shown in fig. 1, 3. Aedeagus as shown in fig. 2, 3. Body length $0.7-1.3 \mathrm{~mm}$. ............... G. boleti

26 (24). Pronotum with scarce, small punctation; middle with 2 longitudinal rows of some punctures and with large, often confluent, shallow foveola.

Subgenus Phaenogyra Mulsant et Rey, 1872

27 (28). Entire body black, sometimes dark brown, glossy. Legs and antennae yellow or pale brown. Entire surface of head with even, sparse, small punctation. Surface of pronotum with even, small punctation of round, scattered, numerous punctures. Posterior angles of elytra with dense, rough punctation. Elytra and abdomen with weak reticulate microsculpture 7 th and 8th abdominal tergites as shown in fig. 3, 5. Aedeagus as shown in fig. 4, 5. Body length 1.2-1.4 mm. ............................. G. polita

28 (27). Head, pronotum and elytra dark brown, sometimes black; 1-5th abdominal tergites dark reddish-brown; 6-7th tergites dark brown. Antennae and legs yellow-brown. Vertex with some small, round, faint punctures. Pronotum with even, small punctation of round, scattered, not numerous punctures. Elytra with dense, not rough and small punctation. Posterior margin of 7 th abdominal tergite with transverse row of vertical, short foveola. 7 th and $8^{\text {th }}$ tergites as shown in fig. 3, 9. Aedeagus as shown in fig. 4, 9. Body length $1.3-1.6 \mathrm{~mm}$ G. strictula

We would like to take this opportunity and thank V. V. Barabanova (NHMK), M. M. Bilyashivskiy (ZMTSNU), A. V. Gontarenko (Ukrainian Entomological Society), I. V. Zagorodnyuk (Taras Shevchenko National University of Lugansk), S. V. Konovalov (Ukrainian Entomological Society), V. A. Korneyev (SIZK), L. I. Fally (Dnepropetrovsk National University), V. B. Rizun and T. P. Yanitskij (both SMNL), M. Schülke (Berlin, Germany), A. Solodovnikov, J. Pedersen (both ZMUC), and H. Schillhammer (NHMW) for the opportunity to work with their respective institutional and private collections, and their valuable remarks on this manuscript. The paper was prepared for publication by one of us (S. Glotov) during the extended visit to the Entomology Department of ZMUC. Funding from Dr. Bø je Benzons Stø ttefond awarded to A. Solodovnikov and facilitated that visit, and support from the entire ZMUC-entomology is appreciated. We also thank two anonymous reviewers for valuable comments and corrections.

Ashe J. S. Generic revision of the subtribe Gyrophaenina (Coleoptera: Staphylinidae: Aleocharinae) with a review of the described subgenera and major features of evolution // Quaestiones Entomologicae. — 1984. 20, N 3. - P. 129-349.

Bogdanov Үu. A. Fauna i ekologiya stafilinid Zakarpatja : Avtoreferat diss. ... kand. biol. nauk. - Kiev, 1985. - 23 p. - Russian : Богданов Ю. А. Фауна и экология стафилинид Закарпатья. Автореферат дисс. ... канд. биол. наук. - Киев, 1985. - 23 с.

Cherkunov N. The list of beetles inhabiting in Kiev and its environs // Zapiski Kievskogo obshestva estestvoispytatelei. - 1888. - 10. - Р. 155-165. - Russian : Черкунов Н. Список жуков, водящихся в Киеве и его окрестностях // Записки Киевского общества естествоиспытателей. - 1888. - 10. C. $155-165$.

Erichson W. F. Die Käfer der Mark Brandenburg. Erster Band. Erste Abtheilung. - Berlin : F. H. Morin. 1837. $384 \mathrm{~S}$. 
Ganglbauer L. Die Kafer von Mitteleuropa. Die Käfer der österrichisch-ungarischen Monarchie, Deutschlands, der Schweiz, sowie des franzosischen und italienischen Alpengebietes. 2. Familienreihe Staphylinoidea. Theil I. Staphylinidae, Pselaphidae. - Wien : Carl Gerold's Sohn, 1895. - 881 S.

Hochhuth J. H. Enumeration der in den russischen Gouvernements Kiew und Volhynien bisher aufgefundenen Käfer // Bulletin de la Societe Imperiale des Naturalistes de Moscou. - 1872. - 44, N 3-4. S. $85-177$.

Horion A. Faunistik der mitteleuropäischen Käfer. Staphylinidae. 3. Habrocerinae bis Aleocharinae (Ohne Athetae ). - Uberlingen-Bodensee : P. C. W. Schmidt, 1967. - Bd. 11. - 419 S.

Jakobson G. G. Beetles of Russia and Western Europe. - St. Petersburg : Izdatelstvo A. F. Devrien, 1905-1913. - 533 p. - Russian : Якобсон Г. Г. Жуки России и Западной Европы.- СПб : Изд-во С. Ф. Девриена, 1905-1913. - 533 с.

Joy N. H. A table of British species of the coleopterous genus Gyrophaena Mann // The Entomologist's Monthly Magazine. - 1912. - 48. - P. 148-150.

Klimaszewski J., Webster R. P., Savard K. Review of the rove beetle species of the subtribe Gyrophaenina Kraatz (Coleoptera, Staphylinidae) from New Brunswick, Canada: new species, provincial records and bionomicinformation. Biodiversity, Biosystematics, and Ecology of Canadian Coleoptera II / Eds C. G. Majka, J. Klimaszewski // ZooKeys. - 2009. - 22. - P. 81-170.

Likovsky Z. Beitrag zur Kenntnis der tschechoslowakischen Arten der Gattung Gyrophaena Mannh. // Ac. rer. natur. Mus. Nat. Slov. Bratislava. - 1964. - 10. - S. 51-65.

Lohse G. A. Family Staphylinidae. II // Die Käfer Mitteleuropas / H. Freude, K. W. Harde, G. A. Lohse Krefeld : Goecke et Evers Verlag, 1974. - 5. - S. 1-381.

Smetana A. Genus Gyrophaena Mannerheim, 1830 // Catalogue of Palearctic Coleoptera / Eds I. Löbl, A. Smetana. - Stenstrup : Apollo Books, 2004. - Vol. 2. - P. 442-446.

Mateleshko $O$. Coleoptera (Insecta, Coleoptera) - mycetobionts of fungi of the genus Pleurotus (Fr.) Kumcity of the Ukrainian Carpathians // Naukovij visnik Uzhgorodskogo universitetu (Seriya Biologiya). - 2005. 17. - P. 127-130. - Ukrainian : Мателешко О. Твердокрилі (Insecta, Coleoptera) - міцетобіонти грибів з роду Pleurotus (Fr.) Kumcity Українських Карпат // Науковий вісник Ужгородського університету. Сер. Біологія. - 2005. - 17. - С. 127-130.

Mateleshko $O$. Faunistic findings of rove beetles (Coleoptera, Staphylinidae) from Zakarpat'e Naukovii visnik Uzhgorodskogo universitetu. Seriya Biologiya. - 2007. - 21. - P. 182-186. - Ukrainian : Мателешко O. Фауністичні знахідки жуків-стафілінід (Coleoptera, Staphylinidae) із Закарпаття // Науковий вісник Ужгородського університету. Сер. Біологія. - 21. - Р. 182-186.

Newton A. F., Chacyn C. G., Chandler D. S. Checklist of the Staphylinidae (Coleoptera) of Colombia // Biota Colombiana. - 2005. - 6, N 1. - P. 1-72.

Nikitsky N. B., Osipov I. N., Czemeris M. V., Semjonov V. B., Gusakov A. A. Xylobiontic, mycetobiontic and Scarabaeidae Coleoptera of the biospheric reservation "Prioksko-Terrasnyi" (with these groups' fauna preview of Moscow region) // Collected works of Zoological museum of MSU. - Moscow : MSU publ., 1996. - Vol. 36. - 197 p. - Russian : Никитский Н. Б., Осипов И. Н., Чемерис М. В., Семенов В. Б., Гусаков А. А. Жесткокрылые - ксилобионты, мицетобионты и пластинчатоусые ПриокскоТеррасного биосферного заповедника // Сборник работ Зоологического музея МГУ. - М. : Издво МГУ, 1996. - Т. 36. - 197 с.

Roubal J. Katalog Coleopter (brouků) Slovenska a Podkarpatska. - Praha, 1930. - T. 1. - 527 p.

Rusch J. Untersuchungsergebnisse zum Vorkommen mitteleuropäischer Arten der Gattung Gyrophaena Mannh. in verschiedenen Pilzen (Coleoptera, Staphylinidae, Aleocharinae) // Entomologische Nachrichten und Berichte. - 1990. - 34, N 6. - S. 263-268.

Scheerpeltz O., Höfler K. Käfer und Pilze. - Wien : Verlag für Jugend und Volk, 1948. - 351 S.

Seevers $C$. H. Revision of the North American and European Staphylinid Beetles of the Subtribe Gyrophaenae (Aleocharinae, Bolitocharini) // Fieldiana. - 1951. - 32, N 10. - P. 656-762.

Strand A. Die nordischen Gyrophaena Mannh. (Col., Staph.), mit Beschreibung von zwei neuen Arten // Norsk Entomologisk Tidsskrift. - 1935. - 3, N 6. - S. 395-404.

Strand A. Gyrophaena orientalis n. sp. (Col., Staph.) // Notulae Entomologicae. - 1938. - 18. - S. 39-40.

Strand $A$. Neue paläarktische Arten der Gattung Gyrophaena Mannh. (Col., Staph.) // Norsk Entomologisk Tidsskrift. - 1939 [1935-1940]. - 5, N 3. - S. 108-111.

Strand A. Some remarks on the Genus Gyrophaena Mannh. (Col., Staph.) and the Description of a New Species, Gyrophaena hanseni n. sp. // Norsk Entomologisk Tidsskrift. - 1946 [1943-1946]. — 7, N 5. P. $173-174$.

Strand A. Gyrophaena keeni Casey and G. orientalis A. Str. // Norsk Entomologisk Tidsskrift. - 1968 - 15, N 1. - S. $35-36$.

Wüsthoff $W$. Beitrag zur Kenntnis der europäischen Arten der Gattung Gyrophaena // Decheniana (Bonn). 1937. - 95. - S. 137-146. 